\title{
Sustainable Tourism Development through Events for the Culture Preservation
}

\author{
Amirosa Ria Satiadji \\ MICE and Event Department \\ Sekolah Tinggi Pariwisata Bali \\ Bali, Indonesia \\ amirosaria@gmail.com
}

\begin{abstract}
Bali is a province with the highest number of tourist destination in Indonesia, and the capital city is Denpasar. To make the Balinese culture can sustain, the government of Denpasar city creates events for the culture preservation. This research will study the uniqueness and success of the culture preservation through events in Denpasar, which have been organized by the government (the department of culture). Ethnography is the research method. Literature review, observation, and interview are the techniques to collect information. The benefits of cultural events created by the Department of Culture in Denpasar are: a. to preserve the local genius of Balinese culture, $b$. to develop the cultural activities and creative arts, c. for religious purposes, $d$. as tourist attractions, $e$. entertainments for the communities, f. media empowerment of the artists and its group, g. economic benefits, such as promotional events for the development of tourism sector in Denpasar city, h. to support Puri Agung Satria. The elements of the culture preservation through events in Denpasar are the government, communities, entrepreneurs, the media, and educational institutions. We hope that the above can become guidelines for other tourist destinations in their efforts to preserve their culture and sustain their tourism development.
\end{abstract}

Keywords - Sustainable, Tourism, Culture, Preservation, Event

\section{INTRODUCTION}

Bali is one of tourism destination that is well known in the world. The history of tourism in Bali according to website Biro Humas Bali Province is coincide to Indonesian that is known as a producer of herbs and spices, Bali is known by the world is from culture side. In the 20th centuries, Bali was overpowered by Netherland marked by the fall of kingdom of Klungkung through Puputan Klungkung war in 1908. Since Indonesia was under Netherlands' power, Bali was opened for foreigner visit. It is not only for foreigner as a tourist, the researcher of culture also came to record the unique of art and culture of Bali. It was started by poet, writer and painter the unique of Bali was more separated to International. The information through media by foreiner could attrack the passion of the tourist to visit Bali. The admiration of Bali could arouse of tourists' passion by giving the tittle: The Island of Gods, The Island of Paradise, The Island of Thousand Temples, The morning of the World, etc. (http://www.baliprov.go.id/v1/balipariwisata was downloaded 13th July 2016, at 09.00 pm)
Bali is one of the island in Republic of Indonesia that is consists of more than 17.000 of islands, 34 of provinces, and more than 1100 ethnics. Bali is consists of 9 regencies, 57 districts, and 716 villages. Bali is a province with the highest number of tourist destination in Indonesia. The number of tourist arrival in Bali is as follows:

TABLE I. FOREIGN TOURIST ARRIVAL IN BALI

\begin{tabular}{lc}
\hline & Number of Foreign Tourist \\
\hline 2010 & $2,493,058$ \\
2011 & $2,756,579$ \\
2012 & $2,892,019$ \\
2013 & $3,278,598$ \\
2014 & $3,768,362$ \\
\hline
\end{tabular}

As we see from Table 1, the number of foreign tourists come to Bali is always increasing. Denpasar as the capital city of Bali is the center of tourists, communities, and government activities area. Denpasar is the capital city on the first level since 1958 that was initially was the center of Badung Kingdom, and it ended as the centre of government regency area on the second level in Badung. As the center of government on the first level in Bali and the second level in Badung, making the growth of Denpasar is very high on physical, economic, and social-culture.

Denpasar consists of 4 districts, those are West Denpasar district, East Denpasar district, South Denpasar district and North Denpasar district. On 15th January 1992, The legislation Number 1 Year 1992 about the formation of Denpasar was published. Denpasar city is inaugurated by Minister of Home Affairs on 27th February 1992 so it made a new era for the government performance on the first level area in Bali, on the second level area in Badung and also for Denpasar. For Denpasar this is in new era on government performance and the second level of regional development, the youngest on the first level in Bali Province area.(http://www.denpasarkota.go.id/index.php/profil/6/Sejarah , was downloaded 28th April 2016, at 10.30 am).The most Balinese domiciled in Denpasar. The most intensiveness of citizen in Bali province is in Denpasar. People in Denpasar is separated in Pekraman village. In Bali Provincial Regulation Number 3 Year 2001 Article 1 Number 4 states: 
"Pekraman village is a law community unit in Bali Province that has the unity of tradition and manner socially Hindu community living for generations in Kahyangan 3 or Kahyangan village that has special area and their own wealth and having right to manage their own household"

According to the data of Department of culture in 2012, Denpasar city has 35 Pekraman villages. In 30 Pekraman villages which is separated in 4 districts, there is Banjar Pekraman. Banjar Pekraman is a community which is a part of Pekraman village. Denpasar has a high culture potention. It could be seen by Sanggar and Sekaa art in every village and Banjar pekramen itself. Denpasar has 152 Sanggar and 301 Sekaa (arts group).

By those potential as a big asset that is owned by Denpasar, vision and mission of Denpasar is very real could be applied by government, community, media, industry, and education institution's support certainly. But, it needs a good management so it could reach what we want. In http://www.denpasarkota.go.id/index.php/selayang-

pandang/5/Denpasar-Sekilas (was downloaded 28th April 2016, at $10.00 \mathrm{am}$ ), as for the vision of Denpasar is Creative Denpasar Cultural Perspective in Balance towards Harmony. While the mission of Denpasar are:

1. Cultivating community identity based on Bali's culture

2. Empowering Denpasar city based on local wisdom through creative culture

3. Ensuring good governance through law enforcement

4. Improving public services towards the welfare society

5. Accelerating economic growth and strengthen the resilience of communities through democratic economic system

The culture is unconscious will be an instrument that could unify people around the world to cooperate, and to elaborate in global problem solving through the power called soft power (Direktorat Jenderal Kebudayaan, 2015:16). In this case, we can see how rich is the culture potention in Denpasar that has been managed and showed through various events that is held by the Government of Denpasar, so Denpasar is worthy to be a model in culture preservation based on event.

Nowadays, Denpasar is the center of economy in Bali, Bali tourism is a sector where the economy featured in Bali. It is looked by Bali regional income magnitude of the tourism sector which is directly reflected in higher total revenues of Hotel and Restaurant tax is $30 \%$ of the total local tax revenues Bali province (Bappeda, 2014. Sectoral Contribution to PDRB in Bali Year 2014)

Denpasar as the capital city of Bali has been visited by foreigners that come as tourist to objects in Denpasar and also as the hotel's guest in Denpasar. The number of the tourist staying in Denpasar is as follow:
TABLE II. TOURIST STAYING IN DENPASAR BY CONTINENT

\begin{tabular}{|c|c|c|c|c|c|}
\hline Nationality & 2010 & 2011 & 2012 & 2013 & 2014 \\
\hline Asia Pacific & 120,692 & 138,206 & 131,523 & 108,721 & 98,069 \\
\hline \multicolumn{6}{|l|}{ Excluding } \\
\hline \multicolumn{6}{|l|}{ ASEAN } \\
\hline ASEAN & 10,025 & 9,711 & 11,290 & 7,668 & 8,001 \\
\hline Africa & 427 & 594 & 413 & 380 & 335 \\
\hline America & 11,154 & 13,986 & 12,313 & 10,607 & 9,740 \\
\hline Europe & 112,756 & 112,026 & 99,352 & 82,058 & 67,838 \\
\hline Middle East & 474 & 878 & 848 & 688 & 791 \\
\hline Other & 81 & 762 & 633 & 115,948 & 185,814 \\
\hline \multicolumn{6}{|l|}{ Nationalities } \\
\hline Domestic & 162,448 & 163,836 & 167,167 & 154,054 & 133,542 \\
\hline Grand Total & 418,057 & 439,999 & 423,539 & 480,124 & 504,130 \\
\hline
\end{tabular}

From Table 2, the number of tourist of staying in Denpasar is increasing. While, the number of visitors on tourist objects in Denpasar is as follow in Table 3:

TABLE III. NUMBER OF VISITORS ON TOURIST OBJECTS IN DENPASAR

\begin{tabular}{cccc}
\hline & Domestic & Foreign & Total \\
\hline 2010 & 183,251 & 135,037 & 318,288 \\
2011 & 237,001 & 161,024 & 398,025 \\
2012 & 205,320 & 190,238 & 395,558 \\
2013 & 258,813 & 184,962 & 443,775 \\
2014 & 258,457 & 284,356 & 542,813 \\
\hline
\end{tabular}

As we look in the high progress of tourism in Bali and especially in Denpasar, it is really important for people in Denpasar, through Department of Tourism that has done an activity to conduct culture preservation that is ideal to appoint as a culture preservation model for a cultural tourism destination. According to the speech of Chief Department of Tourism Bali province in development Gong Kebyar Duta Denpasar in 38th Bali Art Festival in 2016, that was held in Dalem Batan KendalTemple, Sesetan Village, South Denpasar district on 30th April 2016 about culture preservation in Denpasar. He said that what has been done by Denpasar by holding culture event every Saturday and Sunday that was held in Puputan filed for Sanggar-sanggar and Sekaa art could be a model for others regencies in Bali province. Besides, becoming a model for others regencies in Bali, this case could be a reference for various regences or cities in others province on sustainable development tourism by the culture that still maintaining the preservation through the event.

There are various interpretations of conservation, but their primary premise is the protection of cultural and natural resources (Timothy \& Boyd, 2003:87).This research will study the uniqueness and success of the culture preservation through events in Denpasar, which have been organized by the government (the department of culture). Althusser (in Ratna, 2010: 185) says that the hegemony serves as a binder, the cement between groups. The regulatory to the other party of tourism is the government. In this research, hegemony theory will be applied in the formation of a consensus in the form of an agreement among government and the community in relation to the preservation of culture in the city of Denpasar. This research will find the model of Denpasar City Government to achieve sustainable tourism development through cultural events. 
The objectives of this study are:

1. To understand the benefits of the implementation of events based on culture preservation in Denpasar.

2. To understand the elements of sustainable tourism development through event in Denpasar.

\section{METHOD}

Ethnography is the Qualitative method applied in this research. Ethnography is the systematic study of people and cultures. It is designed to explore cultural phenomena where the researcher observes society from the point of view of the subject of the study. Interview to the informants related to cultural preservation by the Government of Culture in Denpasar, field observation to the events and art groups, library research are the techniques to collect the information.

\section{Literature Review}

The World Commission on Environment and Development (WCED, 1987(in Jamrozy, Ute. 2007)), declares the mission of sustainable development as meeting the needs of the present without compromising the ability of future generations to meet their own needs. On Joint Regulation of Ministry of Interior and Minister of Culture and Tourism of Cultural Preservation Guidelines No.42 Year 2009/No.40 Year 2009 mentioned that Culture is whole ideas, behavior, and human creation and/or human community on physical or nonphysical that has been obtained through the study process and adaptation on environment. The purpose of culture preservation is marked on regulation itself those are protection, development, and utilization of the dynamic cultural. The explanations are as bellows:

1. Protection is a preventention effort and countermeasures that could cause breakage, lost, or extinction of cultural such as ideas, behavior, and cultural works included value and dignity and also cultural rights caused by human activity or natural processes.

2. Development is an effort on work, that enable the refinement of ideas, behavior, and cultural works such as alterations, additions, or replacements accordance to procedures and norms in the community owners without sacrificing authenticity.

3. Utilization is an effort to use cultural works for the benefit of education, religious, social, economic, science, technology, and culture itself.

In line to culture preservation meaning, Minister Regulation No.18 Year 2016 on Guidelines for the Preparation, Control, and Evaluation of Local Government Work Plan (RKPD) Year 2017 mentioned that the policy development in tourism and creative economy consist of field activities include advertising, architecture, art market and antiques, crafts, design, fashion, film, video and photography, interactive games, music, performing arts, publishing and printing, services computer and software, radio and television, research and development, and culinary. Culture can be only developed because it is reflected, so the culture always supposes to be done. Without reflection, the culture will be gone.

In Bali Provincial Regulation No.2 Year 2012 on Cultural Tourism Bali mentioned that Bali tourism is based on Hinduism and philosophy of Tri Hita Kirana as the main potention by using tourism as ride actualisation, so it would be applied on dinamic interrelation between tourism and culture that making both of them develop in synergy, harmony, sustainable, and be able to give a welfare to community, culture preservation and environment.

Pitana (in Ardika, 2007:84) tourism is also told giving positive impact to Balinese culture such as to strengthen traditional organization as Banjar and Pekraman village, to improve and to grow the awareness on Balinese identity. So that is why, the tourism should be responded wisely by paying attention to Balinese culture itself, so that the sustainability of cultural tourism in Bali would be stronger.

Event is often related to bussiness MICE (Meeting, Incentive, Conference, Exhibition) where the event actually has a broader scope, where MICE is an event, while the event may not necessarily be categorized as MICE. Accroding Shoneand Perry in Berridge (2007:10) it is stated that:

"Special events are the phenomenon arising from those non-routine occasions which have leisure, cultural, personal, or organizational objectives set apart from the normal activity of daily life, whose purpose is to enlighten, celebrate, entertain, or chalenge the experience of a group of people".

According to Getz in Yusni (2013) stated: "special event can play an important roles - as attractions, image makers, animator of static attractions, and catalysts for another developments". As Noor stated (2013: 7), several reasons why many locals government fund activities those are a festival event or exhibition to the region are as bellows:

a. The number of visitor or tourist on events that will be held. Event will be rated success if the number of target visitor match to expectation. The improving impact of the visitor or tourist will improve the local economy.

b. The culture experience for local. Many people do not recognize the culture in their area. By event, it could show the culture to visitor, people will also join and enjoy the culture that has not been seen by them before. This case often happens to the country that has received the influence by outside, so it is needed by government to show the culture in festival design.

c. The improving of human resources. By ability and event that often would be held, so the ability on managing event will be better. The managing of event that involving the employee will contribute on improving the ability and professionalism in an area as event organizer. This cooperation may improve the potention that has had by organizer or professional so it will develop or corporate.

The management on event is really important. It is also can be as a profit on development of cultural tourism in the region. 
Bali has developed Cultural Tourism. Cultural Tourism is a form of development tourism based on culture that contained in an area. According to Resigned in Fyall, Garrod, and Leask (2003) in ethnographic perspective of cultural tourism is "a genre of special interest tourism based on the search for and participatioon in nes and deep cultural experience, whether aesthetic, intellectual, emotional, or psychological". Meanwhile, from the perspective of an anthropology, accroding to Fridgen in Fyall, Garrod, and Leask (2003) cultural tourism is "much more than the rituals, ceremonies, dances residents might perform for tourist at cultural centres or visitors attractions. The richer meaning of culture refers to those activities associated with many private and unknown traditions that are part of the local person's daily life." So, the elements of culture such as handycrafts, gastronomy, traditions, history, music, dance, and architecture, whether unmanaged or staged especially for visitors, can be major visitors' attractions. (Reisinger in Fyall, Garrod, and Leask, 2003).

UNESCO promotes cultural tourism as a means of preserving world heritage, and in many parts of the world it has become a vital means of economics support for traditional activities and local creativity (Richards, 2007: 1). Several important points must be noted on development of cultural tourism are: Local identity, Authentic, Exotic, dan Unusual. According to Thrane in Richards (2007: 7) Cultural Tourism is not so much a process of reversal, but is in fact an extension of everyday life.

There are some regencies and city in Bali province that has special Department to handle about culture those are: Badung. Gianyar, and Denpasar. By special handling, it expected that culture can be handled better. Generally, the Department of Culture in other regencies in Bali merged to the Departement that handling the tourism, education, or youth and sport.

Besides weekly event, the government in Denpasar also shows annual event regularly, those are: in January: The Anniversary of Denpasar, in April: Competition of Beleganjur Sekaa Teruna Teruni, in May: The Opening of Community Art in Denpasar, in June: School holiday is used by Departement of Culture in Denpasar to give the training of traditional art such as rebab, tabuh, kendang and others for free. The training is followed by 500 participants. But, if it is more than 500 participants, the Mayor will accept the training so that they do not stop the oppurtunity for participants. From June to July: The involvement in Balinese art show, in September: Maha Bandana Persada, it is an event to commemorate last minute of Puputan Badung that centered in Banjar Tensiat. This event is followed by exhibition art, culiner, art show, etc. Maha Bandana Prasadha and Puputan Badung Festival is a cultural event in Denpasar that involving all sekaa/art groups in 4 districts in

Denpasar. (http://www.denpasarkota.go.id/index.php/bacasenibudaya/44/Maha-Bandana-Persada, was downloaded 29th April 2016, at 10.30 am). In December: Denpasar Festival, is started by parade that always be showed by Baris dance that pointed to sightseeing logo of Denpasar, the rest is to welcome the new year.

In 2014, from the opening to the ending has been showed by 15 Sekaa art, by giving characteristic art of Denpasar such as 9 kinds of Baris dance. The procession activity of leisure and sun in 2014 was started by praying with the chief of communication forum inter religious people in Denpasar, assembled by various modern dance that will be closed by parade procession culture with 5000 of artists. This event is regularly event that acomodating an activity and art and culutre creativity by forwarding entertainment as a way to celebrate New Year eve. By this effort, it is expected to reach conserving event and Bali art development, empowerment Sekaa, artists, and culture preservation heritage in the form of local wisdom/local genius. (Department of Culture in Denpasar, 2015: 28).

The competition of Utsawa Dharma Gita is not only be competed for Province level but it is held in Denpasar. Dharma Gita as a chant of Hinduism is usually used to accompany various religions especially that related to ritual. One of the effort of conserving and development is through the competition of Utsawa Dharma Gita. This event is expected be able to grow the passion community especially young generation to understand and fathom literature of religion. It is also as an effort to develop talent and creativity of community especially Hinduism young generation through religious chant. The aim of Utsawa Dharma Gita are to give knowledge to kids, teens, and adults to grow their passion on art literature especially Geguritan that becoming one of heritage culture. This is to appreciate the achievement and art lliterature surround the kids, teens, adults, and to show dynamism and culture religious Bali without leaving cultural roots itself.

On development culture value program, there are events that has been done by Department of Culture in Denpasar on event Selayang Pandang of Department of Culture's book (2015: 6-22) as follows:

\section{a. Implementation of Art Creativity}

In Anniversary of Denpasar, it is held several events that having human resources development, sport creativity, art and culture appreciation that encapsulating by tagline "Gebyar Budaya".

b. Preservation and Actualization of Local Art and Culture

By holding of the workshop or training, also space and time to show as a trial that showing through sanggar-sanggar of art that located in Denpasar is one of form of efforts to conserve local art and culture. The event of preservation and actualization local art and culture that has been doing, those are:

1) Showing Sanggar dance, Sanggar music, percussion, and paint, located at Puputan Badung I Gusti Ngurah Made Agung field every Saturday.

2) Workshop or training of Sanggar dance group, music, percussion, paint and chisel.

c. Preparation of Policy on Regional Local Culture

Related to school holiday, it is viewed need to fill the creativity of children by positive event. In 2014, through preparation of policy about regional local culture, Department of Culture in Denpasar did coaching and training flute, fiddle, and percussion with total number 1.750 people from 16th July 
to 16th August 2014. Percussion training was done in Jagadnatha Temple Denpasar. At last training, the participants would be selected and given a workshop itself and would be done again in 2015.

\section{d. Monitoring and Evaluation of Program Implementation}

One of place of preservation and art and culture development that has done is by involving Kindergarten, Elementary in Budaya Gugus show of Kindergarten and Elemantary that is held every Sunday at Puputan Badung (I Gusti Ngurah Made Agung) field that involving 48 teams each districts in whole Denpasar.

\section{e. Giving support, Reward, and Cooperation on Culture} Side

There are 2 rewards that is given to the artist that having credibility on cultural development in Denpasar, the reward is culture Kerti and culture Parama.

\section{f. Facilities and Infrastructure Development of Subak}

The development is done are the construction of Subak's hall, Kulkul's Subak, Penyengker's wall, Temple's improvment, and Pelinggih Subak.

g. Giving Reward for the Development of Literature and Local Culture Knowledge.

The event is done are Ngelawar competiton, making sate renteng and making banten prani that has been done on $16^{\text {th }}$ February 2016.

h. The Facility of Various of Local Culture Development

1) Pedalangan training In 2014, The government of Denpasar through Department of Culture in Denpasar.

2) Wayang show in Kahyangan village's temple and specific events, and also Wayang show in Jagadnatha temple every full moon.

3) Wayang show in out area It is given a chance to wayang show to out area as Art ambassador of the Government of Denpasar as an effort for development and improving the knowledge in Denpasar.

$i$. The implementation of Culture Value Development (Ngelingan Rerainan Sane Utama).

This event is dance show those are sacred and almost extinct that has been done on specific rainanin Pekraman village.

j. Development, Institutional Arrangements, and Evaluation of Subak in Denpasar.

This event is to give a service to Pangliman and Pekaseh every month, while the development of Subak also is done every year.

k. Development, Institutional Arrangements and Evaluation of Pekraman village

This is as a development institutional of Pekraman village and giving an order to kelian pecalang as their action.

\section{Development Fine Arts Training}

Under the leadership of the Mayor Ida Bagus Rai Dharma Wijaya Mantra, Denpasar has vission that is insight creative culturein balance toward harmony, such an umbrella that is contiguous with the central program "City for Children". The Mayor is giving a space to children to join paint training by the schedule every Sunday at 4-6 pm. In 2014, there were 3 locations of training, those are:

1) Puputan Badung I Gusti Ngurah Made Agung field. The training was done by Komunitas Tiga Warna cooperation under Anak Agung Anom Giri and friends. The visitor who brought the children to have recreation in that field is a goal of this event. The participants who came to have recreation, can also filled by paint training.

2) City Park of Denpasar

In this location, the training was aimed to children on Kindergarten and Elemantary level. This event had been cooperated by Sanggar Jepun Putih, model of modern painting under I Wayan Adnyana and friends.

3) Sewaka Dharma Hall Park

This event was cooperated to Sanggar Padmanata as an implementer under I Made Bendhi Yudha and friends. The specification of the training was painting of wayangthat the participants were from Kindergarten, Elementary, Middle School and High School level.

m. Cruising Heritage

Cruising Heritage was an event to recognize and to aim history sites appropriately by young generation as a knowledge to face future challenges by active method, interactive and creative.

\section{n. The Collaboration of Traditional Art and Modern}

One of colaboration between traditional art and modern event that has been done by the Government of Culture in Denpasar that cooperated to the artists of Denpasar was colaboratring traditional wayang Bali to modern wayang (Thailand wayang). There was the difference on showing between wayang Bali and wayang Thailand physically, where wayang Bali was played by 3-4 people and dalang had a role as narrator who did not hold the wayang.

\section{RESULT}

Dra. Ni Nyoman Sujati, MM, Head of Culture Department Denpasar City, said that culture preservation was done by the Chief of Departement of Culture in Denpasar was by empowering people. By various of community that obtained in community such as Banjar that Sekaa, sanggar, and group are in it too. It can be said, the cutting edge of culture preservation in Denpasar is the art of Banjar. Departement of Culture in Denpasar gave a place to artist to show in outdoor and could get an appreciation from the audience those are community, tourists and also fundraising from the Government of Denpasar. Eventhough the nominal relatively small when compared to the expenditure to be incurred for the appearance, 
but it could motivate the artists for giving the best. The fund has been given by the Government of Denpasar could help the artists to rented the vehicle or just to bought consumption to the artists.

Departement of Culture in Denpasar did cultural preservation by revitalizing and reconstructing the arts endangered contained in Denpasar. Departement of Culture in Denpasar gave rewards such as fund that may be able to help for providing costum, giving development, and supporting the artists to conserve the culture continuely (Tut Wuri Handayani).

One of form of culture preservation was to show it. Various of events were held by the Government of Denpasar. If the culture is often showed, it will make a behaviour for the artists and community to enjoy the art. By giving a place for the artists, it is expected by Department of Culture in Denpasar to conserve the culture.

Culture show held every Saturday at Puputan Denpasar field by showing Sanggar-sanggar in Denpasar. Sanggarsanggar have their schedule to show on the stage, it would be started at $4 \mathrm{pm}$ till the end. Others support from Department of Culture to sanggar in Denpasar was providing the certificate to improve the level of sanggar itself. By giving direct monitoring on implementation improving level in sanggar, the Government in Denpasar could watch the progress of the artists in Denpasar.

Culture event is also held every Sunday in Puputan field for groups in Denpasar. In one group, it generally consists of 7 to 9 Kindergartens and Elementary schools. All kind of arts can be showed in this show. But, there is a guidance that has been given to them, that it is not allowed to forward the elements of religion in the show. It is expected that Kindergarten and Elementary based on specific religion do not show religion creativity but it is expected to show creativity such as the development from Balinese culture such as playgame.

In finding basic artists, there was a team of Cultural Department in Denpasar that consist of 80 people that included 15 consultants besides coach and coordinator that having tasks to give the direction related to the art that will be showed, such as karawitan, pedalangan, dance, percussion, etc. The 15 consultantsare: I Nyoman Geguh, I Gusti Ngurah Padang, Gusti Ngurah Suweka, I Wayan Warta, Anak Agung Susilawati, I Ketut Yuliasih, I Wayan Butuantara, Ketut Alit Arini, I Nyoman Astita, I Nyoman Suarsa, I Made Kembar. I Ketut Sukarata, I Nyoman Sudarna, I Gede Sukraka, dan I Ketut Wijana.All the art consultants on duty to give a training to the artists in rotation in whole area in Denpasar.

To appreciate the existance the artists and people who had service for Denpasar, there would be a reward that given by the Government of Denpasar. There are 2 categories of rewards, those are:

\section{a. Kerti Budaya}

It is a reward that given for Anniversary of Denpasar to the artists that having age above 50 years, born and dedicating in Denpasar.

\section{b. Parama Budaya}

It is a rewards that given to people who had service and acting in Denpasar, such as Lembaga Perkreditan Desa (LPD), Subak, Pekraman village, and Education.

In interview that has been done at the backstage of Angsoka Taman Budaya on 6th July 2016 at 2 pm, it was explained by I Nyoman Suarsa, Consultant of Denpasar Government of Culture about the idea to make art program that activating art potention of the community in Denpasar. Mr. I Nyoman Suarsa is an artist, consultant of Department of Culture in Denpasar, Coach team and researcher of Department of Bali province. At the beginning, (the show is on Saturday and Sunday at Puputan field) this event is held by not receiving any fundraising from local government. But, by looking at this regular event that held at center of the city, local government paid attention to it so that finally they supported this event by giving fundraising to stimulate the spirit for Sanggar-sanggar and schools that will be showed on that event, and becoming regular agenda for Local Government in Denpasar.

For Denpasar, Government attention, it is not only pointed to kids as a successor of cultural but it also to generation that has been working productive, until the elder that long time ago was a great artist in Denpasar. Government attention to 3 generations is an important thing on sustainable culture preservation. This is an amazing idea that obtaining by Government of Denpasar as an example for others area that willing to conserve their culture.

Elders are culture asset that must be taken care. Their existence can be an example for next generation. Their ability can inspire kids and children to be more creative. By giving a place to elders, it will give motivation so they can do creativity on art so it can conduct their talent. That makes them feel healthy, happy and be noted. Then, kids can be encouraged to love their culture so they will always learn so that a culture will always be conserved.

One thing that should be remembered, Denpasar is a city that has heterogen citizen, inhabited by people from several of locals and even around the world. So that it is really important to take care the art and culture of Balinese community especially in Denpasar.

When we train to be able to dance and tabuh, it surely needs to think the output. Especially on art learning, the output must be clear. For the example, learning math is used on working in the office. So, to study art, it should have a space. There is a performance stage in Denpasar that is "Nganyarin". When a temple is built and it must have a ceremony, we can ask art group to the government, so they will come to dance and beat when the ceremony is held and the costing is from the Government. It is budgeted for 6 temples every year. That place will be given to the artists. In the past, people trained art only in temple, but now there has been made a place to continue the show.

Every the end of the year, there will be a show from all the participants of Sanggar around Denpasar, as for the number of people who will dance together are about 4000-5000 dancers. PendetDance and Baris Dance is compulsory dance to be showed. This is a pride for the dancers. Nowadays, every 
sanggar in Denpasar is subventioned by the Local Government. Such farmer, the seed is not only planted but it should be given the fertilizer so that the result will be good. The seed will develop better. Eventhough it is IDR 1.500.000 X 180 Sanggar, it is amazing work that has been done by the Local Government of Denpasar. Eventhough it is small, but this is an attention from Government and surely it will support the artist to more creative in their culture preservation. This is the only one way that only done by the Government of Denpasar and becoming an agenda.

The government hold an important role. Besides the Government, freelance also takes place as giving fundraising in coorporate social responsibility, as in Denpasar Festival event. Media is also important, related to community to raise the culture, as given by rubric culture.

Previously, Department of Culture is merged to Departement Education and Culture. But, it is because the budget is not enough to make the culture awake, so Department of Education is separated from Department of Culture. The role of Department of Culture is very important because successor cadre for culture is in there. The art must be powered in education side. For the example, if it is forced in Banjar, it is possible do not come, but if it is at school, they can always come to train. When Denpasar festival, school was invited to join for show to prove that Balinese art was taught at school itself.

Without commitment from all parties in culture preservation, it cannot be done. If the leader still establishes a great decision in culture preservation, surely all the parties will follow the decision itself, and the culture preservation can be done continually now.

Department of Cultural in Denpasar also gives a place for art and culture development that located in Denpasar. One of it is through innovative such as modern music that is showed in art Bali Festival. In various of festivals those are held by Denpasar such as Denpasar Festival, also there will be several show such as band, creativity on fashion product that is demonstrated and sold, craft, culinary and etc.

Other informant in this research are: Drs. I Ketut Gede Suaryadala (head of art division in culture department of Denpasar city), Mr. I Ketut Suandita, S.Sn (artist and culture department staff of Denpasar city), Mrs. Ni Made Suryani, S.St, M.Si (head of performance and marketing division in culture department of Denpasar city), Mrs. Ni Made Wintari, S.Sn (coach and staff in culture department of Denpasar city), Mr. I Made Wedana (head of Adat in culture department of Denpasar city), Mrs. Ria Mariani (private sectors), and Mrs Dewiyati as a staff in culture department of Denpasar city. The utilization of Culture in Denpasaras the summary of the interview, are:

\section{a. Religious}

The art is in Bali is based on Hinduism, basically it is aimed as a worship way and offering to God. By the intense of culture preservation such as sacred dance, percussion, and the others art that related to religion, certainly it coud be used for various of Hinduism ceremonies.
In Bali is known "Ngayah", that is the art, aimed to religion without requesting paid but as an offering to God. The art was within, it could put the value of religion more within. By beating or doing other art, their value of religion that contained inside the culture could be put inside the artists and the audience, and it would be a life stlye and behaviour on daily life in the future.

b. Preservation

Giving a place for art and culture distribution to community to have more progress and learned, so that the culture will always be maintained. When the culture could be an attention to the world, it will arrise the love to the culture, then it will also arrise the willingness to maintain, so what is the pride of the local culture will be more awake. The enthusiasm of children in watching and it is seldom to imitate the movement, mimic and the voice, it could grow feeling and have willingness to learn the culture itself. Besides, the parents also come to watch the show so that to strengthens kinship of culture.

c. Economy

The economy advantage is one of what we could have through tourism sector. Culture creation event gives a space to community, stakeholder, and Goverment to coorporate in event performance. Various of products could be sold or at least is introduced to the toursits. Accommodation service and transportation have improving because the number of tourists that willing to visit to the festival that is held so the tourism business also feel the impact of the festival performance. Then, the economy impact could be felt directly by festival performance in an area.

1) As a place to local promotion

The hectic rating and community who come to the event will also invite the journalists to look for what happened in an area. Besides, the tourist and community will also upload the photos or tell the Festival to their friends and family so the name of an area will be raised.

2) Tourism

One of the impact from the event that is held routinely every Saturday and Sunday in Puputan field is proliferation activities by tourism event called City Tour, it is seen by improving the number of international and local tourists to Puputan field to watch the culture show that is held by Denpasar city tour, that generally consists of Catur Muka statue, Bali People Struggle Monument, Puri Agung Satria Denpasar, Museum of Bali, Badung Market, Jagadnata Temple, Puputan field, Art centre/WerdiBudaya, etc.

In addition, it is a tourist attraction, by the appereance of culture ambassador potention through festival that is held, the Government of Denpasar could also display the best art ambassador in every regions in Indonesia. Aside from it, it is a reward to the best artist, the performance is out area in Indonesia also is a form of promotion to tourism destination in Bali itself. It will make more people to know the beauty of art in Bali outside. 
d. Support from the King who live in Denpasar, that is in Puri Agung Satria

There is a Festival that is followed by the Kings who live in Republic of Indonesia. The Festival is held alternately in various of areas in Indonesia. On the departure of King from Puri Satria will always be accompanied by the best art ambassador of Denpasar, by showing the best performance in every place the performance of Kings festival.

\section{CONCLUSIONS}

1. The benefits of culture events created by government of culture in Denpasar city are:

a. Culture preservation, that is by maintaining the local wisdom/local genius/values of Bali, by learning and showing the culture continuely.

b. Art development, by accomodating the activity and creativity art and culture

c. Religion, that is to show the art that can be as a tourist attraction and entertainment media for community.

d. Development of the artists and Sekaa(art group).

e. Economy, as local promotion media by various of impacts, and also for the tourism development in Denpasar.

f. Support to the Kings who lived in Denpasar.

2. The elements (stakeholder) in culture preservation through event in Denpasar are:

a. The government holds important role in culture preservation in various of events that is held by the Government of Denpasar.

b. Community, that is consists of Pekraman village, Banjar, Sanggar, Sekaa, association in community.

c. Entrepreneur that related to tourism product industry both goods and service.

d. Media is able to give information extensively about the performance an event by various of culture products inside the event.

e. Education institution engages the students so they can learn directly their own culture so that the regeneration from the existance of the culture would happen.

\section{REFERENCES}

Ardika, I Wayan. (2007). Pusaka Budaya \& Pariwisata. Bali: Pustaka Larasan
Berridge, Graham. (2007). Events Design and Experience. London: Butterworth-Heinemann

Dinas Pariwisata Kota Denpasar. (2014). Denpasar Tourism Data. Denpasar: Dinas Pariwisata Kota Denpasar

Dinas Kebudayaan Kota Denpasar. (2015). Selayang Pandang Kegiatan Dinas Kebudayaan Kota Denpasar. Denpasar: Dinas Kebudayaan Kota Denpasar

Direktorat Jendral Kebudayaan. (2015). Road to World Culture Forum 2016. Jakarta: Kementerian Pendidikan dan Kebudayaan Republik Indonesia

Fyall, Alan; Garrod, Brian; and Leask, Anna. (2003). Managing Visitors Attractions New Direction. Great Britain: Oxford, Rochester.

Jamrozy, Ute. (2007). Marketing of tourism: a paradigmshift toward sustainability. USA: California School of Business and Organizational Studies, Alliant International University, San Diego, California. www.emeraldinsight.com/1750-6182.htm

Noor, Any. (2012). Manajemen Event. Bandung: Alfabeta

Noor, Any. (2013). Manajemen Event - Edisi Revisi. Bandung: Alfabeta

Peraturan Daerah Provinsi Bali Nomer 3 Tahun 2001 pasal 1 angka 4

Peraturan Menteri Dalam Negeri Nomor 18 Tahun 2016 tentang Pedoman Penyusunan, Pengendalian, dan Evaluasi Rencana Kerja Pemerintah Daerah Tahun 2017. Direktorat Jenderal Bina Pembangunan Daerah Kementerian Dalam Negeri Tahun 2016

Peraturan Bersama Menteri Dalam Negeri dan Menteri Kebudayaan dan Pariwisata tentang Pedoman Pelestarian Budaya Nomor 42 Tahun 2009 / Nomor 40 Tahun 2009

Richards, Greg. (2007). Cultural Tourism Global and Local Perspectives. New York: Routledge.

Wiarti, Yusni. Jurnal Kepariwisataan, (Volume 12) Nomor 1 Maret 2013. ISSN: 1412 - 5498. Bali: Pusat Penelitian dan Pengabdian Kepada Masyarakat Sekolah Tinggi Pariwisata Nusa Dua Bali

http://www.baliprov.go.id/v1/balipariwisata

http://www.denpasarkota.go.id/index.php/profil/6/Sejarah

http://www.denpasarkota.go.id/index.php/selayangpandang/5/Denpasar-Sekilas

http://www.denpasarkota.go.id/index.php/bacasenibudaya/43/Utsawa-Dharma-Gita

http://www.denpasarkota.go.id/index.php/bacasenibudaya/44/Maha-Bandana-Persada

https://en.wikipedia.org/wiki/Ethnography . (2011). Event Management Kota Denpasar. Denpasar: Pemerintah Kota Denpasar 